ISSN1027-5495. Functional Materials, 23, No.3 (2016), p. 517-520

doi:http://dx.doi.org/10.15407/fm23.03.517

(C) 2016 - STC “Institute for Single Crystals"

\title{
Stamp stress analysis with low temperature nanoimprint lithography
}

\author{
Hongwen Sun, Xiaochao Ma, Chenhui Hu \\ College of Internet of Things Engineering, Hohai University, Changzhou, \\ Jiangsu, 213022, P.R. China
}

Received March 22, 2016

High temperature nanoimprint lithography has the drawback of long process cycle, demoulding difficulty, polymer degradation, thermal stress. Low temperature nanoimprint lithography (LTNIL) can avoid these problems. LTNIL is also ideal for manufacturing biological compatibility samples since the samples do not sustain high temperature. However, LTNIL need to optimize the press parameters in order to fully transfer patterns. Finite Element Method (FEM) is an excellent approach to examine the filling process. The stamp stress was simulated from four points of view, imprint pressure, imprint temperature, stamp pattern and stamp material. It was found that the stress in the stamp corners is especially bigger than other areas, the stress increases with the stamp's aspect ratio increases, and stress distribution is more uniform for dense pattern stamp.

Keywords: Hot embossing lithography, nanoimprint lithography,low temperature, stamp, stress, finite element method.

Высокотемпературная нанопечатная литография имеет такие недостатки как длительный цикл процесса, сложность деформации, деградация полимера, термические напряжения. Низкотемпературная нанопечатная литография (LTNIL) может помочь преодолеть эти проблемы. LTNIL также идеальная для производства биологически совместимых образцов, потому что образцы не испытывают влияния высокой температуры. Однако, LTNIL требует оптимизации параметров печати, чтобы достичь полной передачи рисунка. Метод конечных элементов (FEM) - прекрасный метод для исследования процесса нагрузок. Напряжения в штампе были промоделированы с четырех точек зрения: давление печати, температура печати, рисунок штампа и материал штампа. Было найдено, что напряжения в углах штампа значительно выше, чем в других областях, напряжения растут с ростом соотношения сторон штампа, распределение напряжений более однородно для плотного рисунка штампа.

Аналіз напруги, що виникае при низкотемпературой нанодрукарської літографiï. Хонгвэн Сан, Сяочао Ма, Чэнху Ху

Високотемпературна нанопечатная літографія мае такі недоліки як тривалий цикл процесу, складність деформування, деградація полімеру, термічні напруги. Низькотемпературна нанопечатная літографія (LTNIL) може допомогти подолати ці проблеми. LTNIL також ідеальна для виробництва біологічно сумісних зразків, тому що зразки не зазнають впливу високої температури. Однак, LTNIL вимагає оптимізації параметрів друку, щоб досягти повної передачі малюнка. Метод кінцевих елементів (FEM) - прекрасний метод для дослідження процесу навантаження. Напруження в штампі були промодельовані з чотирьох точок зору, тиск друку, температура друку, малюнок штампа і матеріал штампа. Було знайдено, що напруги в кутах штампа значно вище, ніж в інших областях, напруги зростають зі зростанням співвідношення сторін штампа, розподіл напруг більш однорідний для щільного малюнка штампа. 


\section{Introduction}

Hot embossing lithography (HEL), one of the common nanoimprint lithography (NIL) technique, has the advantage of high resolution, high uniformity and low cost [1]. However, high temperature the process needed leads to many disadvantages, such as long process cycle, demoulding difficulty, polymer degradation, thermal stress and not suitable for part of substrates heating [2]. Low temperature nanoimprint lithography (LTNIL) can avoid the above drawbacks [3,4]. LTNIL can be widely used in the area of biology, medical science, and organic light-emitting because the polymers applied in these areas cannot sustain high temperature $[5,6]$.

There are some researchers conducted the study of LTNIL. Scheer et al. researched the polymer time constants during LTNIL [7]. Chen et al. imprited metal films by NIl with both low temperature and low pressure [8]. They imprinted SU-8 at $45^{\circ} \mathrm{C}$ and NEB-22 at $60^{\circ} \mathrm{C}$. Lu et al. even patterned poly(acrylic acid)/Poly(allylamine hydrochloride) multilayer films by room temperature imprinting [9]. To save cost and time, it is necessary to study the LTNIL process by modeling and simulation. Kim et al. used a viscoelastic model to simulate low temperature NIL with temperature range $T_{g}<T<T_{g}+40^{\circ} \mathrm{C}$ [10]. Song et al. researched room temperature NIL by simulating different imprinting speeds and patterns [11]. However, there are few references studying the stamp stress by simulation. This contribution applied Finite Element Method (FEM) to research the stress of nanoimprint stamp at low temperature.

\section{Modeling}

The FEM software ANSYS was used to set up modeling. The element type of stamp is Plane 42 and element type Hyper56 for the resist. Fig. (1) shows one of our models. The length of the groove is $300 \mathrm{~nm}$ and depth is $50 \mathrm{~nm}$. The thickness of the resist is $100 \mathrm{~nm}$.

The common used resist Poly(methyl methacrylate) (PMMA) was taken as the resist in the simulation. For stamps, different materials, silicon ( $\mathrm{Si}$ ) and nickel (Ni) was used for comparison purpose. The parameters of them were shown in Table 1.

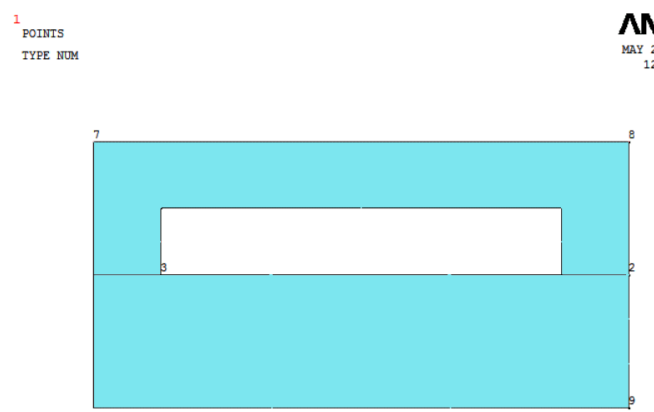

Fig. 1. Typical FEM Model (above is the stamp with one groove and the bottom is the resist).

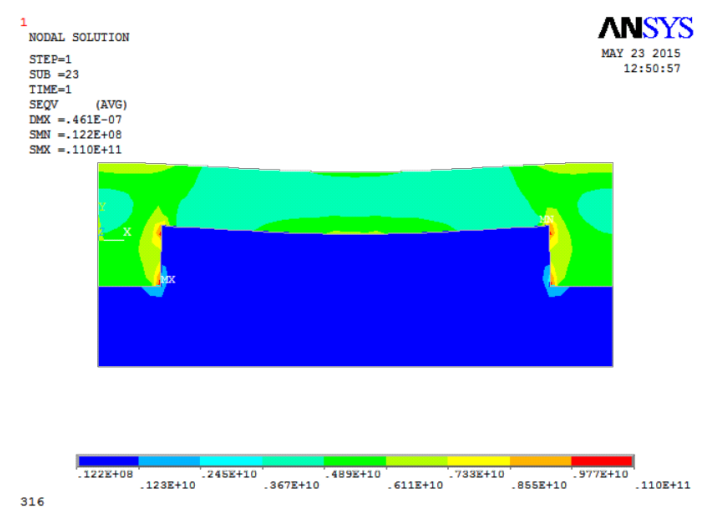

Fig. 2. Stamp stress distribution with $5 \mathrm{GPa}$ pressure and 400K.

\section{Results and Discussion}

\subsection{Imprint Pressure Variation}

Firstly, 5GPa was applied to the above model. The stress distribution under $400 \mathrm{~K}$ was given in Fig. (2). From the figure, it can be found that the resist filled the stamp well. The stress in the borders between the stamp and the resist are obviously larger than the inner area. The stress in the corners is especially bigger than other areas. The central area has the lowest stress.

To further lower the stress, it is necessary to find the minimum pressure needed to help the resist fully fill the stamp cavities. After several simulation, we found $1.7 \mathrm{GPa}$ is the proper pressure for the combination of $\mathrm{Ni}$ stamp and PMMA resist at $400 \mathrm{~K}$. Although, the stress distribution is similar to the above $5 \mathrm{GPa}$ situ-

Table 1. Parameters of Different Nanoimprint Stamps

\begin{tabular}{|c|c|c|c|c|c|}
\hline Material & $\begin{array}{c}\text { Elastic } \\
\text { modulus, GPa }\end{array}$ & $\begin{array}{c}\text { Poisson's } \\
\text { ratio }\end{array}$ & $\begin{array}{c}\text { Density, } \\
\mathrm{kg} / \mathrm{m}^{3}\end{array}$ & $\begin{array}{c}\text { Thermal conductivity } \\
\text { coefficient }\end{array}$ & $\begin{array}{c}\text { Specific heat } \\
\text { capacity, J/kg }\end{array}$ \\
\hline $\mathrm{Ni}$ & 207 & 0.29 & 8900 & 71.4 & 460 \\
\hline $\mathrm{Si}$ & 190 & 0.30 & 2330 & 149.0 & 700 \\
\hline
\end{tabular}




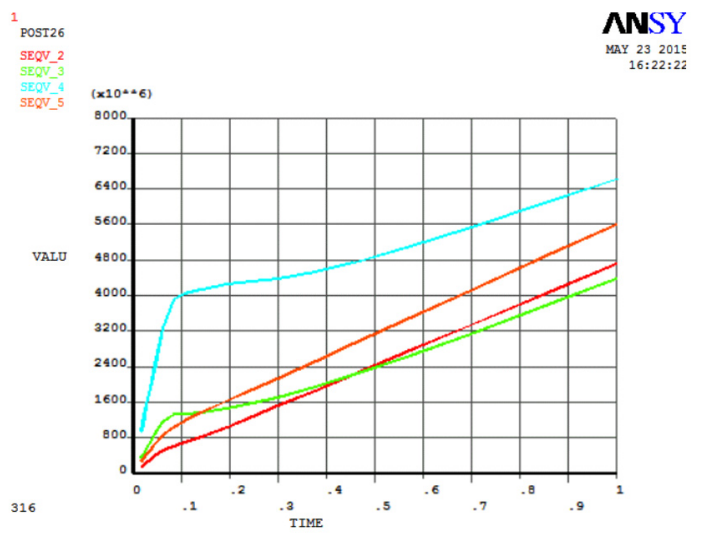

Fig. 3. Stress change during the imprint for four typical points in the stamp under $390 \mathrm{~K}$.

ation, the imprint time increases when the imprint force decreases.

\subsection{Imprint Temperature Variation}

To simulate the stress of the stamp in NIL with different temperatures, we analyzed the stamp stress with temperature at $390 \mathrm{~K}, 400 \mathrm{~K}$ and $410 \mathrm{~K}$. Fig. 3 shows the stress change during the imprint for four different points in the stamp under $390 \mathrm{~K}$.

For three temperatures, the stress distribution shows little variation. Therefore, it can be concluded that the temperature has little effect on the stamp stress when imprint is conducted under low temperature, which is still greater than the glass transition temperature of the resist.

\subsection{Imprint Temperature Variation}

Another three grooves pattern structure was designed and simulated for further research the relationship between the stamp's pattern structure and the stress after imprinting. Figure 4 gives the three grooves model. The length of each groove is $100 \mathrm{~nm}$ and depth is still $50 \mathrm{~nm}$. The thickness of the resist is $100 \mathrm{~nm}$. Fig. 4 also shows the stress distribution with the imprint condition of temperature $400 \mathrm{~K}$ and pressure $5 \mathrm{GPa}$.

From Fig. 4, it can found that the minimum and maximum stress is $0.472 \times 10^{8} \mathrm{~Pa}$ and $0.124 \times 10^{11} \mathrm{~Pa}$, respectively, which is both larger than the minimum and maximum stress in one groove stamp situation. It means that when the stamp's aspect ratio increases, the stress will increase corresponding.

For comparison, the typical four points were chosen again to show the stress change with imprint time. These four points are at the same place as in Section 3.2. Fig. (5) shows the corresponding stress change with imprint time. It can be noticed that stress distribution is more uniform for three groove stamp, which means

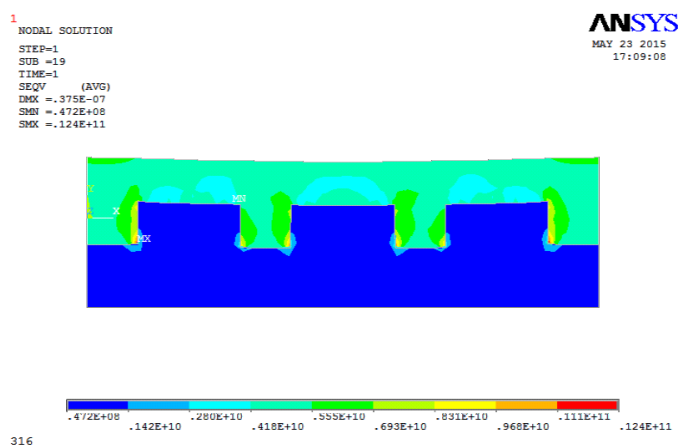

Fig. 4. Three grooves stamp model and stress distribution with the imprint condition of temperature $400 \mathrm{~K}$ and pressure $5 \mathrm{GPa}$.

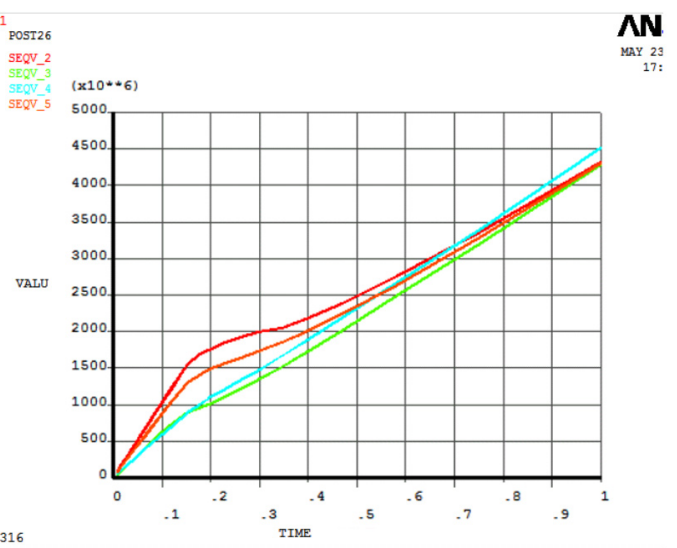

Fig. 5. Four points' stress change with imprint time using three grooves stamp.

the stress of different places does not vary too much.

\subsection{Stamp Material Variation}

For analyzing the stress after NIL using different stamp materials, the first model with one groove was chosen. In general, the stress distribution of $\mathrm{Ni}$ and $\mathrm{Si}$ stamp has similar characteristics. However, when finding the minimum pressure in order to fully fill the cavity of the stamp, we found $1.5 \mathrm{G} \mathrm{Pa}$ is the proper pressure for the Si stamp and PMMA resist at 400K, which is lower than the situation of $\mathrm{Ni}$ stamp. This can be explained by that the hardness of $\mathrm{Si}$ is larger than $\mathrm{Ni}$.

\section{Conclusions}

Low temperature nanoimprint lithography can reduce thermal cycle and stress. They can be widely used in different areas, especially in the medical and organic lighting areas since the sample substrate needn't suffer high temperature. Analyzing LTNIL by Finite Element Method can save time and cost. The stamp stress was simulated from four points of view, that is Imprint Pressure, Imprint Temperature, Stamp Pattern and Stamp Material. The 
stress in the borders of the stamp is obviously larger than the inner stamp area. When the stamp's aspect ratio increases, the stress will increase corresponding. The stress distribution is more uniform for dense stamp patterns. The stress distribution of $\mathrm{Ni}$ and $\mathrm{Si}$ stamp is similar. However, the Si stamp has smaller minimum pressure in order to fully fill the cavity of the stamp.

\section{Acknowledgements}

This research was supported by "the Fundamental Research Funds for the Central Universities" with project No. 2015B22514.

\section{References}

1. S.Y. Chou, P. R. Krauss, P. J. Renstrom, Appl. Phys.Lett., 67, 3114, 1995.

2. C.M. Sotomayor Torres, S. Zankovych, et al., Mater. Scie. Engin., 23, 23, 2003.

3. M.M. Alkaisi, R.J. Blaikie, S. J. McNab, Microelectron. Eng., 57-58, 367, 2001.

4. N.Ikutame, K. Kawaguchi, H. Ikeda, et al., J. Appl. Phys., 114, 083514, 2013.

5. A.Pepin, P. Youinou, V. Studer, et al., Microelectron. Eng., 61-62, 927, 2002.

6. J. Kettle, S. Whitelegg, A. M. Song, et al., Nanotechnology, 21, 075301, 2010.

7. H.C. Scheer, N. Bogdanski, M. Wissen, et al., J. Vac. Sci. Technol. B: Microelectron. Nanomet. Struct., 23, 2963, 2005.

8. H.L. Chen, S. Y. Chuang, H. C. Cheng, et al., Microelectro. Eng., 83, 893, 2006.

9. Y. Lu, J. Sun, J. Shen,, Langmuir, 24, 8050, 2008.

10. N.W. Kim, K.W. Kim, H.C. Sin, Microelectron. Eng., 85, 1858, 2008.

11. J.H. Song, H. Huh, S.H. Kim, H.T. Hahn, Mater. Sci. Forum, 505-507, 85, 2006. 